\title{
Modelling and mapping resource overlap between seabirds and fisheries on a global scale: a preliminary assessment
}

\author{
Vasiliki S. Karpouzi*, Reg Watson, Daniel Pauly \\ UBC Fisheries Centre, Aquatic Ecosystems Research Laboratory, University of British Columbia, 2202 Main Mall, Vancouver, \\ British Columbia V6T 1Z4, Canada
}

\begin{abstract}
Coexistence of foraging seabirds and operating fisheries may result in interactions such as competition for the same prey resources. We used GIS-based modelling at a scale of $0.5 \times 0.5^{\circ} \mathrm{spa}-$ tial cells to: (1) map the foraging distribution of seabirds; (2) predict their annual food consumption rates in a spatially explicit manner; and (3) estimate a spatially explicit seabird-fisheries overlap index. Information on population size, diet composition and foraging attributes of 351 seabird species was compiled into a Microsoft Access database. Global annual food consumption by seabirds was estimated to be 96.4 million tonnes (95\% CI: 78.0 to 114.7 million tonnes), compared with a total catch of nearly 120 million tonnes by all marine fisheries. Krill and cephalopods comprised over $58 \%$ of the overall food consumed and fish most of the remainder. The families Procellariidae (albatrosses, petrels, shearwaters) and Spheniscidae (penguins) were responsible for over $54 \%$ of the overall food consumption. Seabird foraging distribution maps revealed that areas around New Zealand, the eastern Australian coast, and the sub-Antarctic islands had high species richness. However, temperate and polar regions supported high seabird densities and most food extracted by seabirds originated there. Furthermore, maps of food consumption rates revealed that most food consumed by seabirds was extracted from offshore rather than nearshore waters and from areas where seabird-fisheries overlap was low. The resource overlap maps identified 'hotspots' of highest potential for conflict between fisheries and seabirds. Thus, this study may provide useful insight when developing management approaches for designing offshore marine conservation areas.
\end{abstract}

KEY WORDS: Seabird-fisheries interactions $\cdot$ Resource overlap $\cdot$ Foraging distribution $\cdot$ Seabird food consumption

\section{INTRODUCTION}

Fisheries have dramatically expanded in the last few decades (Pauly et al. 2002, 2003, 2005, Myers \& Worm 2003) and now extract from the world's oceans well over 120 million tonnes of resources annually (Pauly et al. 2002). Global fishing operations reduce populations of target and non-target species and alter food web function and ecosystem structure (Pauly et al. 1998, Moore \& Jennings 2000, Jennings et al. 2001). To quantify these effects, these reductions must be analysed on a large scale and within an ecosystem-based context. To date fisheries assessment approaches have used time series analyses to study the variability of target species over time. These approaches, however, often fail to detect variability in space. Maps have been proposed as a complementary tool for fisheries science (Pauly et al. 2003, Worm et al. 2003) to help make the necessary transition towards ecosystem-based management.

Moreover, the incorporation of top predators, such as seabirds, into large scale ecosystem approaches has been acknowledged as an integral part of understanding food web structure and ecosystem functions (e.g. 
Cairns 1992, Fowler 1999). Seabirds are abundant, conspicuous and can indicate ecological effects of oceanographic changes (e.g. sea surface temperature anomalies in the Southern Indian Ocean; Weimerskirch et al. 2003). They also may signal changes in the condition and availability of prey stocks (e.g. Barrett \& Krasnov 1996, Kitaysky et al. 2000) and serve as indicators of ecosystem change (e.g. Ainley et al. 1995, Weimerskirch et al. 2003).

Several authors have attempted to determine the trophic role of seabirds in marine food webs by estimating the amount of food they consume. These studies have focused on only one (e.g. Lorentsen et al. 1998, Rodhouse et al. 1998, Bunce 2001) or a few seabird species breeding at one location (e.g. Croll \& Tershy 1998, Green et al. 1998, Goldsworthy et al. 2001, Barrett et al. 2002). Efforts to estimate food consumption on larger spatial scales (e.g. within a large marine ecosystem or throughout an ocean basin) have been sporadic and have focused on a single species (e.g. Woehler 1995). Brooke (2004) was the first investigator to tackle the issue of seabird food consumption on a global scale; his study included most seabird species. He estimated an annual food consumption of 70 million tonnes for the world's oceans. The present study represents the first attempt to express global food consumption rates by seabirds on a spatial scale. In addition we investigated how the world's seabirds may interact with fisheries and identified areas of highest concern.

Interactions between fisheries and seabirds have also received considerable attention (e.g. Furness 1982, Montevecchi 2002). Some studies have shed light on how entanglement in fishing gear increases seabird mortality and affects seabird populations (e.g. Belda \& Sanchez 2001, Tuck et al. 2003). In addition human exploitation of marine resources has provided an increased opportunity for some seabirds to take advantage of prey (as discards) that would otherwise be unavailable to them. This form of interaction results in increases in seabird population sizes (e.g. Furness et al. 1988, Votier et al. 2004); however, seabird populations rely heavily on the fate and future of fisheries (e.g. reduction in discarding by fisheries appears to affect entire seabird communities; Reeves \& Furness 2002).

Other forms of interaction between fisheries and seabirds result from sharing the same resource. Resource overlap represents the extent to which 2 consumers overlap in the exploitation of the same resource in the same area and time (Hurlbert 1978). Although resource overlap describes a more neutral form of interaction, it may be regarded as an indicator of potential competition (Hurlbert 1978). In this case competition occurs only when a resource is limited. Mod- ern fisheries selectively remove large quantities of biomass from marine ecosystems (e.g. Pauly \& Christensen 1995). Their vast expansion worldwide in the last few decades has resulted in the collapse of many fish stocks (Pauly et al. 2002), overexploitation of high trophic level prey and a worrisome trend toward fishing down the food web (Pauly et al. 1998). As a result industrialized modern fisheries may negatively affect seabirds through depletion of resources that would otherwise be available as prey (e.g. Wanless et al. 2005). Prey depletion by fisheries may also trigger indirect trophic cascading effects and enhance competition with other top predators that rely on the same prey as seabirds (Verity et al. 2002).

Potential competition between seabirds and fisheries for the same prey has been given considerable attention (e.g. Furness 1982, Furness \& Birkhead 1984, Montevecchi 2002, Cowx 2003); however, few studies have actually quantified this form of competition. Duffy \& Schneider (1994) proposed the use of Horn's (1966) modification of Morisita's (1959) index for the assessment of resource overlap. Resource overlap has been estimated between the penguin population and the krill fisheries in the South Shetland Islands (Ichii et al. 1996, Croll \& Tershy 1998). Moreover, Goldsworthy et al. (2001) used a percentage similarity index (\% PSI; sensu Schoener 1970) and assessed low overlap between seabird populations and the Patagonian toothfish Dissostichus eleginoides fishery around Macquarie Island.

In this study we attempted to express on a spatial scale the amount of food seabirds consume and identify areas where competition between seabirds and fisheries may be possible by addressing 3 goals: (1) to map the foraging distribution of seabirds; (2) to estimate seabird annual food consumption rates per cell; and (3) to obtain an estimate of a seabird-fisheries overlap index per cell by comparing seabird food consumption rates from (2) with the spatially disaggregated fisheries catches database of the Sea Around Us Project (Watson et al. 2004; www.seaaroundus.org).

\section{METHODS}

We compiled information for 351 marine bird species (belonging to 4 orders and 14 families) in a Microsoft Access database. Of these species 334 are traditionally considered to be seabirds. The remaining 17 were species of sea ducks that that breed inland, but prey upon small fish and invertebrates that occur along the coast. We gathered information using the following databases: (1) Aquatic Sciences and Fisheries Abstracts; (2) Web of Science, Institute for Scientific Information; and (3) BioSciences Informa- 
tion Service of Biological Abstracts. These cover peerreviewed journals and other literature sources. Information was also extracted from the following online databases: (1) Avibase - the world bird database (www.bsc-eoc.org/avibase); (2) the United Nations Environment Programme - World Conservation Monitoring Centre Species Database (http://www.unepwcmc.org/species/dbases/about.cfm); (3) BirdLife International (www.birdlife.net); (4) the National Audubon Society Christmas Bird Count (www.audubon.org/ bird/cbc/); (5) Birds of North America Online (http:// bna.birds.cornell.edu/BNA/); and (6) Wetlands International (www.wetlands.org).

Our database contains information on seabird taxonomy, population dynamics, diet composition and foraging ecology. The above information was used to estimate annual food intake rates of seabirds as well as to map their foraging distribution. Furthermore, spatially explicit food consumption rates were then compared with spatially disaggregated annual fisheries catches to obtain a map of resource overlap between fisheries and the world's seabirds. We used a GISbased modelling approach and the same spatial grid of $0.5 \times 0.5^{\circ}$ cells developed by the Sea Around Us Project (Watson et al. 2004) to compare seabird food consumption per cell with fisheries catch.

Food consumption by seabirds. Information necessary to estimate the seabirds' daily food intake (DFI) and, hence, their annual food consumption included: (1) body mass (in g) of seabirds species taken from Dunning (1993) and Schreiber \& Burger (2002); (2) basal and field metabolic rates (BMR and FMR, respectively, estimated using order-specific allometric equations from Ellis \& Gabrielsen 2002; in $\mathrm{kJ} \mathrm{d}^{-1}$ ). BMR and FMR were used to estimate energy requirements (ER) of seabirds in the non-breeding and breeding season, respectively; (3) a matrix of standardized diet composition; and (4) population sizes of breeding seabirds (see below).

Daily food intake (DFI) was estimated using a bioenergetic model created by the ICES Working Group on Seabird Ecology (ICES 2000):

$$
\mathrm{DFI}_{i}=\frac{\mathrm{ER}_{i}}{\sum_{j=1}^{G} \mathrm{DC}_{i j} \times \mathrm{ED}_{j}} \times \frac{1}{\mathrm{AE}_{i}}
$$

where $\mathrm{DFI}_{i}$ denotes daily food intake for each seabird species $i, \mathrm{ER}_{i}$ is the energy requirements for each $i$, $\mathrm{DC}_{i j}$ is the fraction of food item $j$ in the diet of each $i$, $\mathrm{ED}_{j}$ is the mean energy density of each prey $j$ (see Table 11 in Karpouzi 2005). $\mathrm{ED}_{j}$ values were available either at the species or the taxon level for prey items (see Table 11 in Karpouzi 2005). $\mathrm{AE}_{i}$ is the mean food assimilation efficiency for each $i$, and $G$ the total num- ber of food groups (Table 1) encountered in the diet of each $i . \mathrm{AE}_{i}$ was assumed equal to $75 \%$ (Gabrielsen 1994, ICES 2000, Barrett et al. 2002) unless speciesspecific information was found in the literature.

To estimate seabird species' annual food consumption $\mathrm{DFI}_{i}$ was estimated separately for the breeding and non-breeding season by considering $\mathrm{ER}_{i}$ for the breeding season equal to FMR (ICES 2000) and equal to $2.5 \times$ BMR for the non-breeding season (ICES 2000). The length of the breeding season was assumed equal to incubation period plus time from hatching to leaving the nest or burrow plus $20 \mathrm{~d}$ (Cramp 1985). Following Brooke (2004) we assumed a coefficient of variation of $50 \%$ for population size to estimate minimum and maximum confidence intervals for global food consumption rates.

Consumption by seabirds was specified using 25 food groups (see Table 1 for description). Food groups were compiled based on the taxonomic groups represented in the Sea Around Us database (Table 1). Total food consumption was estimated per spatial cell based on the seabird density of each cell (see below).

At-sea distribution of seabirds. Data on seabirds' global breeding distribution and demography were tabulated by species, year and breeding location. Each breeding location was assigned a population size for each breeding species and original census year. Population sizes are usually expressed in the literature as breeding pairs (bp). The following formulae were used to estimate non- and prebreeders present in colonies (1) for single-egg laying species $(\mathrm{bp} \times$ $0.6)+(\mathrm{bp} \times 0.7)$; and (2) for multi-egg laying species $(\mathrm{bp} \times 0.6)+(\mathrm{bp} \times 1.0)(\mathrm{ICES} 2000)$. These calculations assume that nonbreeders comprise $30 \%$ of the breeding population and that the fledging success of singleegg and multi-egg clutch species is 0.7 and 1.0 chick per pair, respectively (Cairns et al. 1991). The population size table covered the years from 1950 to 2003. For years when population sizes were not available, data were interpolated assuming a linear relationship between the available data points. Data were also extrapolated from the first available data point back to 1950 as well as from the last available data point to 2003 assuming no change in the population size had occurred.

We modelled the at-sea distribution of seabirds using information on their distributional range. Primarily, all 351 species were assigned a distributional range defined by the northernmost and southernmost latitude for each species. Distributional ranges were taken from Harrison (2004), the Global Register of Migratory Species (GROMS; www.groms.de) and BirdLife International. The species were divided into 4 groups according to the distance they fly from their colony to feed. The following groups emerged. Group A 
Table 1. Food groups used to express standardized diet composition data, calculate annual food consumption rates and assess resource overlap between seabirds and fisheries on a global scale. Food groups were compiled based on the taxonomic groups represented in the Sea Around Us Project database

\begin{tabular}{|c|c|}
\hline Food group & Taxa included \\
\hline Perch-like & $\begin{array}{l}\text { Perciformes, Anarhichadidae, Mugilidae, Labridae, Apogonidae, Diplodus spp., Scomber japonicus, } \\
\text { S. scombrus, Emmelichthys nitidus nitidus, Seriolella brama, Dicentrarchus labrax, Pagellus acarne, } \\
\text { Lithognathus mormyrus, Pomatomus saltator, Thyrsites atun }\end{array}$ \\
\hline Gadiformes & $\begin{array}{l}\text { Boreogadus saida, Gadus morhua, G. macrocephalus, Macruronus novaezelandiae, M. magellanicus, } \\
\text { Pseudophycis bachus, Micromesistius poutassou, Micromesistius australis, Pollachius virens, Merluccius } \\
\text { spp., Theragra chalcogramma, Eleginus gracilis, Pleurogrammus monopterygius, Pleurogrammus azonus }\end{array}$ \\
\hline Beloniformes & Belone belone belone, Scomberesox saurus saurus, S. saurus scombroides, Cololabis saira \\
\hline Scorpaeniformes & Cottidae, Prionotus spp., Trigla spp. \\
\hline Flatfishes & Pleuronectidae, Reinhardtius hippoglossoides, Solea spp. \\
\hline Anchovies & Engraulis encrasicolus, E. australis, E. anchoita, E. capensis, E. japonicus, E. mordax, E. ringens \\
\hline Atherinidae & Silversides \\
\hline Carangidae & Decapterus spp., Trachurus declivis, T. mediterraneus, T. trachurus, T. symmetricus \\
\hline Channichthyidae & Crocodile icefishes \\
\hline Clupeidae & $\begin{array}{l}\text { Clupea harengus, C. pallasii, Sardinops sagax, Etrumeus teres, E. whiteheadi, Sardina pilchardus, } \\
\text { Sprattus sprattus }\end{array}$ \\
\hline Osmeridae & Smelts \\
\hline Exocoetidae & Flyingfishes \\
\hline Macrouridae & Grenadiers \\
\hline Myctophidae & Electrona antarctica, Gymnoscopelus nicholsi, Lampanyctus spp., Lampichthys spp. \\
\hline Nototheniidae & $\begin{array}{l}\text { Notothenia rossii, N. coriiceps, N. nybelini, Gobionotothen gibberifrons, Lepidonotothen squamifrons, } \\
\text { Pleuragramma antarcticum, Dissostichus eleginoides, D. mawsoni }\end{array}$ \\
\hline Synodontidae & Lizardfishes \\
\hline Sand lances & Ammodytes hexapterus, A. americanus, A. marinus \\
\hline Capelin & Mallotus villosus \\
\hline Goatfishes & Upeneus spp. \\
\hline Pacific salmonids & Oncorhynchus spp. \\
\hline Redfishes & Sebastes spp. \\
\hline Fish & Other taxa, not included in the above food groups \\
\hline Cephalopods & Teuthida, Kondakovia longimana, Loligo spp., Illex spp. \\
\hline Decapods & Shrimps, prawns, Brachyura \\
\hline Krill & Euphausia superba, E. crystallorophias, Meganyctiphanes norvegica, Thysanoessa spp. \\
\hline
\end{tabular}

was made up of nearshore species that forage within $1 \mathrm{~km}$ from shore and included some species of cormorants, gulls, terns, pelicans, seaducks and some alcids. Group B consisted of coastal species that travel up to $10 \mathrm{~km}$ from shore to find food and included mainly species of cormorants, gulls, terns and seaducks as well as some alcids. Group C consisted of seabird species of the continental shelf that forage within $200 \mathrm{~km}$ from land and contained some storm petrels and shearwaters, some boobies, crested penguins, alcids, and larger-bodied gulls and cormorants. Each breeding population was assumed to disperse evenly from the colony in all directions. The probability of occurrence was assumed to decrease linearly with distance from land, to zero at the maximum reported foraging range. Group D comprised pelagic species that forage in deeper, offshore waters at distances $>200 \mathrm{~km}$. This group includes pelagic, deep diving penguins, as well as albatrosses, prions, petrels, gannets, some boobies, some shearwaters and storm petrels. Group D was further divided into 3 subgroups: (1) species that travel distances $>200 \mathrm{~km}$ to feed; however, the probability of occurrence decreases linearly to zero at the maximum reported foraging range; (2) species whose probability of occurrence was described by a trapezoidal probability distribution (i.e. occurrence was assumed to be uniformly highest within a threshold distance from the breeding colony and then to decrease linearly to zero at the maximum reported foraging range); and (3) 12 Puffinus species (i.e. P. assimilis, P. bulleri, P. carneipes, $P$. creatopus, $P$. gravis, $P$. griseus, $P$. huttoni, $P$. nativitatis, $P$. newelli, $P$. pacificus, $P$. puffinus and $P$. tenuirostris). These Puffinus spp. breed in areas of the Southwest Pacific and South Atlantic oceans. At the end of the breeding season they migrate to feed and winter in the waters of the North Pacific and the North Atlantic oceans (e.g. Guzman \& Myres 1983, Camphuysen 1995, Gould et al. 1997, 1998, Spear \& Ainley 1999, Ito 2002). 
On occasion shearwaters form flocks and feed with surface-schooling tunas (Au \& Pitman 1988, Au 1991). These seabirds benefit when tunas drive prey closer to the surface where they can be reached by surface divers. Such foraging behaviour has been documented, for instance, for Wedge-tailed shearwaters that feed with yellowfin tuna Thunnus albacares and less frequently with Skipjack tuna Katsuwonus pelamis in the eastern tropical Pacific Ocean (Au \& Pitman 1988, Au 1991). The same habit is also shown by Greater shearwaters that feed with tunas in the Atlantic Ocean (Clua \& Grosvalet 2001). Hence, to map the foraging distribution of the abovementioned 12 species of shearwaters we assumed that their distribution matched that of 3 species of schooling tunas (yellowfin tuna, southern bluefin tuna T. maccoyii and northern bluefin tuna $T$. thynnus; available online at www.seaaroundus.org).

For all 4 groups seabird distribution was further constrained by the distribution of prey that occurs in the diet of the avian predators. Prey distribution maps are available from the Sea Around Us Project.

Seabirds-fisheries resource overlap. To assess interactions between seabirds and fisheries we estimated a resource overlap index, $a$, that uses the amounts of prey taken jointly by seabirds and fisheries. We used the indices of Morisita (1959) and Horn (1966) as modified by Kaschner (2004). Kaschner (2004) applied a weighting factor to measure the importance of spatial cell of either very low seabird food consumption rates, or very low fisheries catches or both. Thus, the resource overlap index was as follows:

$$
a=\frac{2 \times \sum_{i=1}^{G} p_{i j} \times p_{f j}}{\sum_{i=1}^{G} p_{i j}^{2}+\sum_{f=1}^{H} p_{f j}^{2}} \times\left(p Q_{i} \times p C_{f}\right)
$$

where a takes values from 0 to 1 , with 0 indicating no overlap and 1 complete overlap; $p_{i j}$ is the proportion of a food group $j$ to the total amount of food taken by a seabird $i_{i} p_{f j}$ is the proportion of $j$ in the catch of the fishery $f_{i} G$ denotes the number of food groups taken by $i$, and $H$ the number in the catch of the fishery $f_{i} \mathrm{pQ}_{i}$ and $\mathrm{pC}_{f}$ denote the proportion of food taken by $i$ and the proportion of food caught by $f$ at each cell. The resource overlap index, $a$, was quantified on a global scale and allocated to each spatial cell using seabird densities for each cell and the disaggregated fisheries catches from the Sea Around Us Project (Watson et al. 2004).

We also calculated the proportion of seabird food consumption by areas of overlap with fisheries. Logarithmic transformation of the $y$-axis was required, because the proportion of food consumed in cells with overlap $>0.3$ was very close to 0 .

\section{RESULTS}

\section{At-sea distribution of seabirds}

Fig. 1 shows the predicted foraging distribution of all seabird species combined and seabird density (i.e. number of individuals $\mathrm{km}^{-2}$ ). Areas along the coast of New Zealand, the eastern, southeastern coast of Australia, the sub-Antarctic islands and the Patagonian Shelf are characterized by the highest number of foraging seabird species in the world (Fig. 1a). In addition, Hawaii, the Caribbean Sea, the California current system and the waters around and north of the Galápagos Islands are the only areas north of the equator with high numbers of foraging species (Fig. 1a). Temperate and polar regions of the northern hemisphere have the lowest number of foraging species (Fig. 1a); however, these areas are characterized by high seabird densities (Fig. 1b).

\section{Total annual food consumption by seabirds}

The estimated annual global food consumption of all seabird species combined was 96.4 million tonnes (95\% CI: 78.0-114.7 million tonnes). Krill and cephalopods comprised more than $58 \%$ of the overall food consumption (krill, 37.8\%; cephalopods, 20.5\%, Fig. 2). Fish, for which no catch is reported, and myctophids were the 3rd and 4th ranked prey, respectively, consumed by seabirds (Fig. 2). The families Procellariidae and Spheniscidae were responsible for more than $54 \%$ of the overall food consumption.

Mapping food consumption rates of all seabirds combined (Fig. 3) revealed that a considerable amount of food is consumed by seabirds over the continental shelves (e.g. along the western and eastern coasts of South America, the northwestern Pacific Ocean [Okhotsk Sea and the Sea of Japan] and the continental shelves of the North Atlantic Ocean, Fig. 3). However, most of the food is taken from offshore areas (e.g. offshore waters of the southwestern Pacific Ocean and the Southern Ocean, Fig. 3) particularly from the cold temperate and polar waters of the world (Fig. 3) where seabirds forage in high densities.

\section{Spatially explicit resource overlap between seabirds and fisheries}

Mapping the overlap between all seabirds and fisheries on a global scale revealed that, for the 1990s, overlap mostly occurred in the cold temperate waters of the northern hemisphere (Fig. 4). In the North Atlantic Ocean 'hotspots' of high overlap were present 

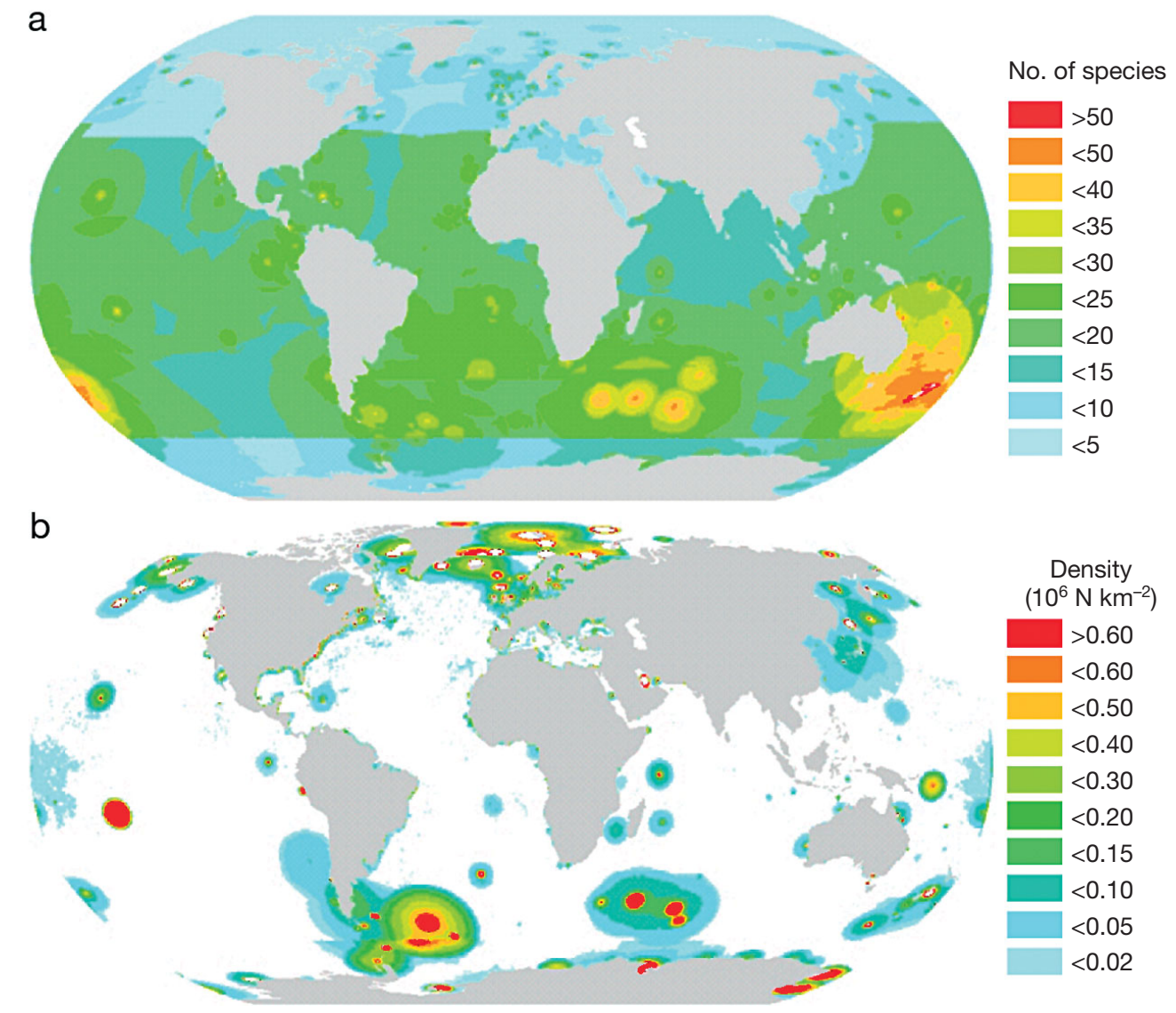

Fig. 1. Predicted foraging distribution of seabird species during an average year in the 1990s, expressed in (a) number of seabird species per spatial cell, and (b) number $(\mathrm{N})$ of individuals per $\mathrm{km}^{2}$

throughout the shelf areas of Europe and along the coast and shelf areas of eastern Canada. In the North Pacific Ocean high overlap was estimated for the Asian shelves and the eastern Bering Sea (Fig. 4).

In the southern hemisphere resource overlap between seabirds and fisheries was high in the productive waters of the Humboldt and Benguela currents (Fig. 4). The waters around New Zealand were also characterized by very high overlap (Fig. 4). Lastly, the Patagonian Shelf and the areas around the Antarctic Peninsula were both of high relative importance (Fig. 4).

In the $1990 \mathrm{~s},<1 \%$ of all food taken by seabirds was consumed in areas of high spatial overlap with commercial fisheries (Fig. 5). In other words, most of the food consumed by seabirds originated from areas where resource overlap was very low (Fig. 5).

\section{DISCUSSION}

The first major step of this work was the creation of a database to incorporate and computerize information on the biology, ecology and demography of the world's seabird species. Only recently has the need been expressed for transforming published information on marine biodiversity into a digital, more interactive and

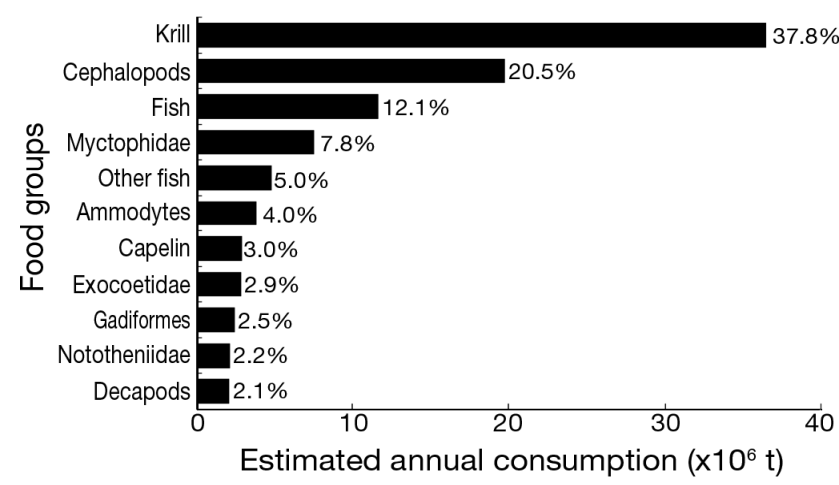

Fig. 2. Percentage contribution of food groups (see Table 1) in the estimated annual global food consumption of all seabird species combined. 'Other fish': anchovies $(1.4 \%)$, Clupeidae $(1.1 \%)$, Sebastes spp. $(0.7 \%)$, Carangidae $(0.5 \%)$, goatfishes $(0.4 \%)$, perch-like fishes $(0.2 \%)$, flatfishes $(0.2 \%)$, Beloniformes $(0.1 \%)$, Scorpaeniformes $(0.1 \%)$, Channichthyidae $(0.1 \%)$, Osmeridae, Atherinidae, Synodontidae, Oncorhynchus spp. and Macrouridae $(<0.05 \%$ each) 


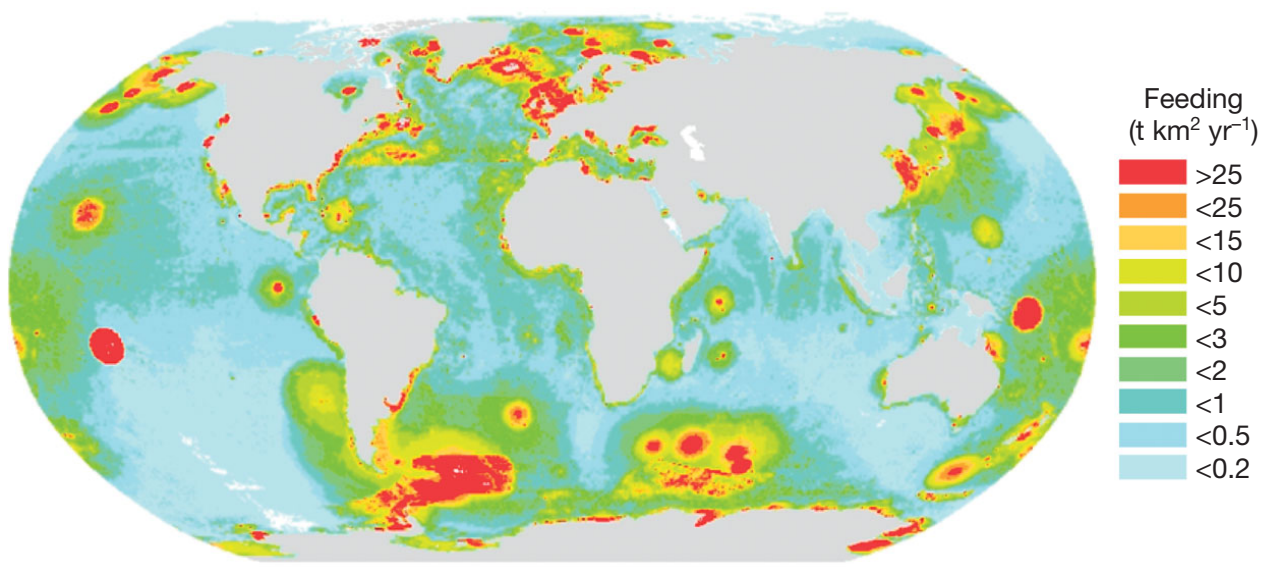

Fig. 3. Predicted global food consumption rate (in tonnes $\mathrm{km}^{-2} \mathrm{year}^{-1}$ ) of all sea-birds combined for an average year in the $1990 \mathrm{~s}$

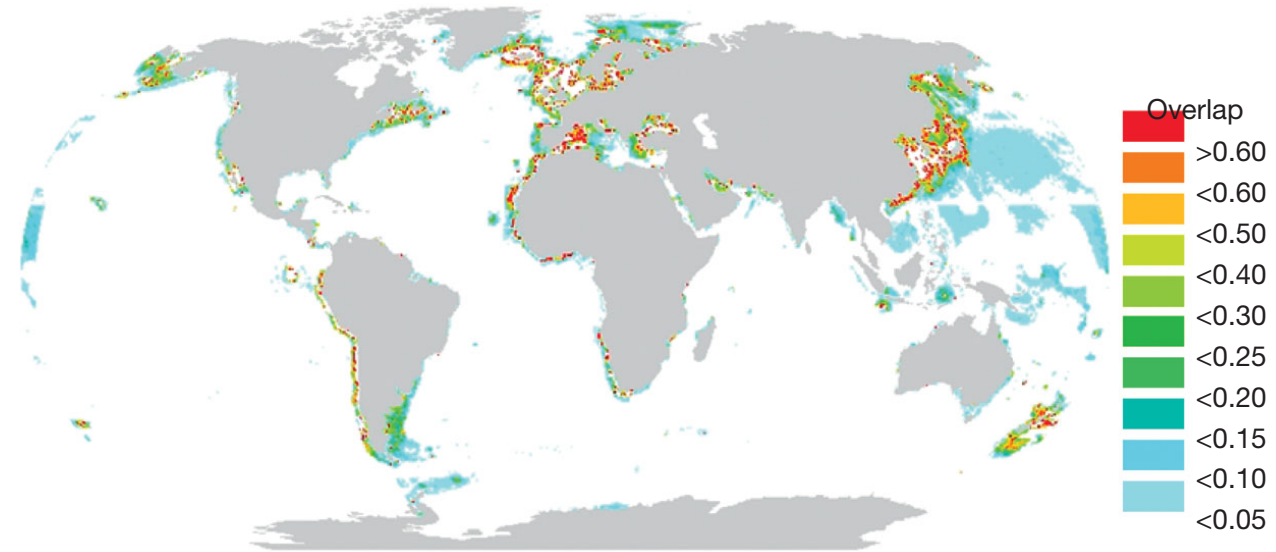

Fig. 4. Estimated resource overlap between all seabirds and fisheries for an average year in the 1990s

readily accessible form (Bisby 2000, Costello et al. 2006 and references therein). Our efforts primarily focused on the extraction of data on seabird population sizes, habitat, and feeding preferences from over 3000 scientific articles published from the early 1900s to the present. Then data were transformed into computerized

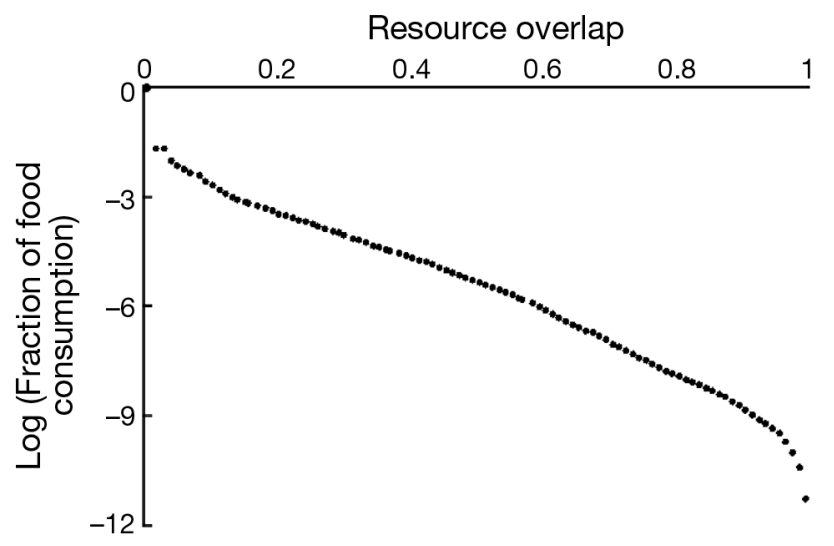

Fig. 5. Fraction of food consumed by seabirds in the 1990s by areas of overlap with fisheries information that was further analysed to explore population trends, seabird foraging distribution patterns and interactions with fisheries.

\section{Global estimates of total annual food consumption by seabirds}

Our maps of food consumption rates for all seabirds of the world were a first attempt to quantify and express where nesting seabirds extract their food from the world's oceans. Previous publications have quantified regional food consumption by seabirds (e.g. North Atlantic Ocean: Cairns et al. 1991, Lilliendahl \& Solmundsson 1997, Barrett et al. 2002, 2006; South Pacific Ocean: Muck \& Pauly 1987; Southern Ocean: Adams et al. 1993, Cooper \& Woehler 1994). Brooke (2004) was the first to provide a global estimate of food consumption by seabirds. Our estimate of worldwide consumption was about $30 \%$ higher (96.4 million tonnes) than Brooke's (2004) estimate of 69.8 million tonnes. This is probably because we considered more seabird species (351) than Brooke (2004) did (309). Moreover, Brooke 
(2004) assumed, conservatively, that one non-breeder exists for every breeding pair to estimate global population size. As a result, his estimate of population size was 0.7 billion individuals, versus 0.9 billion individuals in our estimate. However, Brooke (2004) agreed that a 'liberal' global population estimate (i.e. breeding pairs multiplied by 5 for longer-lived species and by 4 for other groups) is plausible. Our global food consumption estimate was, thus, similar to Brooke's (2004) 'liberal' estimate.

Uncertainty associated with the parameters of the bioenergetic model used for estimating food consumption by seabirds may affect the model's outputs. Error can be associated with both the metabolic parameters (e.g. Furness 1978) as well as the population size estimates (Goldsworthy et al. 2001, Brooke 2004). Indeed, bioenergetic models are primarily sensitive to changes in the demographic parameters such as the population size estimates. In our case very few population time series that spanned from the early 1950s to the present were available to us. Three examples here are the Guanay cormorant Phalacrocorax bougainvillii, the Peruvian booby Sula variegata, and the Peruvian pelican Pelecanus thagus breeding in Peru; population sizes for all 3 species were available from 1953 to 2000 (Jahncke 1998, Crawford \& Jahncke 1999, Sueyoshi 2000). However, for $97 \%$ of seabird populations, population size estimates used before 1970 were based on backward extrapolation (i.e. we assumed no change in population size). More data on seabird population sizes then became available and the percentage of interpolated population estimates decreased to $86 \%$. Thus, uncertainty in the model estimates increases both with the lack of population size data and due to the assumption of no trend when extrapolating population sizes. When we assumed a coefficient of variation of $50 \%$ in the population sizes as Brooke (2004) did, $95 \%$ confidence intervals provided food consumption estimates that ranged from 78.0 to 114.7 million tonnes. Although these confidence intervals are large they suggest that seabirds around the world consume significant quantities of marine resources that are 70 to $95 \%$ of the total fisheries catch (i.e. ca. 120 million tonnes of resources annually if account is taken of fish illegally caught and not reported and of fish that are discarded; Pauly et al. 2002).

Energy requirements of seabirds fluctuate seasonally because the energetic costs of various stages in the life cycle of mature seabirds differ (e.g. Furness 1978, Koteja 1991, Ellis \& Gabrielsen 2002). Therefore, energy demands of seabirds were estimated here using BMR and FMR for the breeding and the nonbreeding season, respectively. However, BMR and FMR values were estimated using allometric equations (see 'Methods' and Ellis \& Gabrielsen 2002), which may entail bias and may affect the model's predictions. Good empirical measurements of FMRs (e.g. with the use of doubly-labelled water [DLW]; Uttley et al. 1994, Golet et al. 2000) measure energy consumption of freeliving animals and give estimates with an accuracy of $\pm 7 \%$ (Nagy 1989, Nagy et al. 1999). However, such measurements are available for only a small number of seabird species. Thus, sensitivity analysis that compares how metabolic parameters derived from either equations or empirical DLW experiments drive the bioenergetic model outputs could not be undertaken.

Quantitative diet composition data were available for $50 \%$ of the 351 seabird species. As a result additional uncertainty in the food consumption estimates may have resulted from our assumption that the diet composition for 177 of seabird species was the same as that for another congeneric species. Other sources of error may include differences in the energy density of prey attributed to differences in the relative status (i.e. size, age and reproductive state), or seasonal or geographical differences and influences. Mårtensson et al. (1996) determined that revision of prey calorific density used to estimate the food consumption of minke whales Balaenoptera acutorostrata in the northeastern Atlantic Ocean resulted in food consumption estimates that vary by 10 to $15 \%$ (translating to ca. 300000 tonnes of food). Therefore, accurate measures of prey energy density for a range of species are important in generating more accurate model predictions (Tierney et al. 2002).

\section{At-sea distribution of seabirds}

This was a first preliminary attempt to construct a GIS-based model that allows mapping the at-sea distribution of all seabird species of the world. A previous attempt to explore global patterns of species richness was carried out by Chown et al. (1998) who compiled data on the breeding locations and foraging-wintering distributions of 108 Procellariiform species. Their analysis revealed that the waters around New Zealand, the sub-Antarctic islands of the Southern Ocean and Hawaii hold the largest number of Procellariiform species (Chown et al. 1988). The same distribution patterns were also found when we considered all seabird species (Fig. 1a). These areas of high species richness comprised biodiversity 'hotspots'. In addition maps of seabird foraging densities showed that the polar waters of the globe hold the highest seabird densities (Fig. 1b). They also represented areas where the most food is taken by seabirds (Fig. 3). In the southern hemisphere these areas coincided with areas where prey, such as the Antarctic krill, squid and the mesopelagic fishes of the families Nototheniidae and Myctophidae, 
were abundant (e.g. Rodhouse et al. 1996, Lascara et al. 1999, Duhamel et al. 2000). In the northern hemisphere most feeding occurred in areas that depicted the distributions of prey, such as capelin Mallotus villosus, sand lance Ammodytes spp. and herring Clupea harengus (e.g. the waters of the North Atlantic Ocean; Fig. 3).

Our efforts to model the at-sea distribution of seabirds focused primarily on expressing in a quantitative manner what is already known from the literature about seabird biology and biogeography. The first 3 modelling steps dealt with areas where seabirds breed, the latitudinal range within which they occur and the distance they fly away from shore in search of prey. This is a rather crude, probably simplistic modelling approach and associated uncertainty may stem from the assumption that the probability of occurrence for a seabird species declines linearly with distance from shore. Such a unimodal response curve is likely inadequate to describe the occurrence of seabird species in marine foraging habitats and future work will focus on refining this assumption.

At-sea foraging distributions of seabirds were further refined based on prey distributions available from the Sea Around Us Project. Although the underlying assumption is that seabirds feed where prey occurs, diet for nearly half of the seabird species is not known and therefore was assumed to be similar to that of a congeneric species, adding more uncertainty to our model's output. Lastly, the use of tuna distributions to depict the distribution of 12 migratory shearwater species must be viewed as a stopgap. Associations between shearwaters and feeding surface-schooling tunas have been documented for tropical waters only (Au \& Pitman 1988, Au 1991, Clua \& Grosvalet 2001). However, the same is not true for temperate waters where shearwaters also occur (e.g. Guzman \& Myres 1983). Thus, we may have underestimated the number of seabird species and failed to predict the occurrence of shearwater species in certain cold temperate areas (e.g. the Gulf of Alaska; Fig. 1). Certainly, this feature of the distribution maps will have to be improved.

Several variables that define pelagic foraging habitats and the at-sea distribution of far-ranging seabirds have been used in the literature (e.g. Rodhouse et al. 1996, Hyrenbach et al. 2002, 2006, Ainley et al. 2005); these are sea surface temperature, sea surface salinity, seafloor depth, and chl a concentration. Moreover, Nel et al. (2001) recently correlated satellite-tracked greyheaded albatross movements with weekly satellitederived sea surface height anomaly (SSHA) data. Indeed, positive and negative SSHA (i.e. warm and cold eddies) may contain elevated stocks of potential prey that attract far-ranging pelagic seabirds (Nel et al. 2001). In the future, our efforts will focus on determin- ing how environmental and oceanographic factors affect the distribution of seabirds at sea. Our ultimate goal will be to build global species- or family-specific predictive models of preferred habitat for foraging seabirds.

\section{Resource overlap between fisheries and seabirds}

Our assessment of resource overlap between fisheries and seabirds showed that seabirds extract most food from offshore areas where overlap with fisheries is low (Fig. 5). Our maps of spatial resource overlap identified that 'hotspot' areas occur mainly on or along the continental shelves (Fig. 4). This is not surprising because fisheries that target demersal, benthic and bentho-pelagic organisms cover the shelves surrounding continents and islands, whereas fisheries operating in the open ocean target mainly tuna, billfishes, and other large pelagic species (Pauly et al. 2003), which are not prey items in the diet of seabird species.

The study of seabird food consumption has often served as the means of investigating the potential for competition between seabirds and fisheries (e.g. Croll \& Tershy 1998, Green et al. 1998, Bunce 2001, Goldsworthy et al. 2001, Furness 2002). Indeed, fisheries and foraging seabirds inevitably interact in a number of ways (review by Montevecchi 2002). Three main effects of fisheries on seabirds are: (1) consumption of and dependence on fisheries discards (e.g. Votier et al. 2004); (2) increased mortality from entanglement in fishing gear (e.g. Melvin \& Parrish 2001); and (3) competition for the same prey targeted by the fisheries for human consumption (e.g. Furness 2002).

In this study we quantified the potential for competition that resulted from seabirds feeding on fish and other aquatic organisms and fisheries targeting the same resources (Type 3 interactions) by measuring a resource overlap index. However, for seabird populations that rely heavily on discards (e.g. Votier et al. 2004) discards found in the diet of seabirds were not included in the consumption rate and overlap calculations. Therefore, in areas of the world where seabirds rely on discards for food (e.g. the North Sea: Garthe et al. 1996; the Mediterranean Sea: Oro \& Ruiz 1997) we believe that overlap was underestimated.

Entanglement of seabirds in fishing gear was also not taken into account in our modelling approach. Mortality of seabirds due to entanglement in fishing gear usually results from seabirds being hooked or dragged underwater and drowned while trying to feed on bait or on fish caught by long-line gear. In net fisheries birds are caught and drowned in the nets while diving in pursuit of their prey (Moore \& Jennings 2000). Such interactions cannot be quantified as out- 
lined in the methodology section here. Thus, in areas where such interactions are prevalent we believe that competition between seabirds and fisheries was underestimated. For instance, mortality from fishing gear has been blamed for population declines in several endangered seabird species in the waters of the Southern Ocean (e.g. wandering albatross Diomedea exulans, Cherel \& Weimerskirch 1996; white-chinned petrel Procellaria aequinoctialis, Weimerskirch et al. 1999; grey-headed albatross Thalassarche chrysostoma, Nel et al. 2000; Tristan albatross Diomedea dabbenena, Cuthbert et al. 2005). Indeed, in these areas where long-lining is a dominant fishing method very low or no resource overlap was predicted in our study (Fig. 4). However, the expansion of the Sea Around Us catch database to allow for the inclusion of information on fishing gear worldwide will allow the development of maps that reveal what types of gears are used in different areas (Watson et al. 2006). Overlay of gear maps with seabird distribution maps will also allow us to explore spatial overlap between seabirds and fisheries that are attributed to entanglement in fishing gear (Watson et al. 2006).

Regardless of all the biases and limitations of our modelling approach we believe that even a simple model may provide useful insights on how different seabird species distribute their foraging efforts on a large spatial scale. In addition, our maps of resource overlap identified areas of the world that may present the potential for competition between seabirds and fisheries. Resource overlap between fisheries and top predators has only recently been quantified spatially at a global scale for marine mammals (Kaschner 2004, Kaschner \& Pauly 2004, Kaschner et al. 2006). Kaschner (2004) and Kaschner et al. (2006) have developed maps of marine mammal distributions and quantified spatial overlap. Overall, the overlap between marine mammals and fisheries is low; however, in certain shelf areas of the world overlap is highest (Kaschner \& Pauly 2004). Likewise, only a small amount of food consumed by seabirds comes from areas where fisheries operate (Figs. 4 \& 5). In other words, most catches are taken from waters where only a small fraction of the world's seabird population forages.

Our maps of resource overlap identified 'hotspot' areas that have been previously noted in the literature to hold the potential for competition between seabirds and fisheries. These areas have either high seabird densities (e.g. the North Atlantic; Fig. 1b), or a large number of abundant seabird species (e.g. the Patagonian shelf and the Campbell Plateau; Fig. 1a). In particular, in the North Atlantic Ocean, fisheries of capelin and sand eel Ammodytes marinus are expanding to provide raw material for agricultural and aquaculture feed (Carscadden et al. 2002, Huntington et al. 2004). Capelin and sand eel dominate the diet of many seabird populations breeding in the North Atlantic (Carscadden et al. 2002, Davoren \& Montevecchi 2003). As a result, depletion of stocks may lead to conflict between seabirds and fisheries. Similarly on the Patagonian shelf, squid stocks have been maximally exploited and probably overfished (Boyle \& Rodhouse 2005). Published maps of the distribution of effort for squid fisheries (Rodhouse et al. 2000), as well as maps produced for this study (Fig. 4), show substantial apparent overlap with the seabirds that forage in the area (Gremillet et al. 2000, Rodhouse et al. 2000, Croxall \& Wood 2002).

The scientific community is currently undertaking the major task of development of new tools and approaches to conservation and management. Some of the most important issues of global concern include loss of biodiversity, destruction of habitat, sustainable use of resources and governance and management of the high seas. The open oceans are poorly studied, though intensively exploited (e.g. Myers \& Worm 2003, Pauly et al. 2003, 2005). They are a challenge to those interested in protecting marine biodiversity. It is now widely recognized that the establishment of marine reserves in the high seas can generate a wide range of benefits (e.g. protect ecosystem structure and function, reduce overfishing and preserve critical habitat; Gjerke \& Breide 2003, Worm et al. 2003, Pauly et al. 2005). In addition, it is a key mechanism for promoting ecosystem-based management and conservation on larger geographical scales.

For seabirds, a broad consensus exists that the identification of marine important bird areas (IBAs) will make a vital contribution to global initiatives for protection and sustainable management of the oceans, including valuable input to the development of marine reserves in the high seas (BirdLife International 2004). BirdLife International has pioneered IBAs for terrestrial and freshwater ecosystems since the 1980s (www. birdlife.org.uk/action/science/sites). However, the criteria currently in use need to be adapted and applied to marine ecosystems. Our maps identified areas of high conservation concern by revealing where species richness and seabird density are high and where the potential for competition for the same resources between seabirds and fisheries may be prevalent. Thus, spatial modelling of seabird distributions may serve as a useful tool in the effort of identifying and developing standardised global criteria for the establishment of marine IBAs to conserve marine biodiversity and critical habitat and promote ecosystem-based management (Gjerke \& Breide 2003, BirdLife International 2004, Cheung et al. 2005). 


\section{General summary}

The maps developed from this analysis are useful in understanding distribution patterns of seabirds at sea and how their consumption of prey resources is allocated in the waters around the globe. These maps are also an important step in identifying which areas of the world present the potential for competition between seabirds and fisheries when sharing the same prey resources between these 2 marine ecosystem components is considered. Spatial modelling of seabird distribution may prove an essential tool for establishing criteria when designing offshore marine protected areas for conserving biodiversity and critical habitat. Meanwhile, maps of interactions between seabirds and fisheries may help concentrate conservation efforts primarily on those areas of highest concern.

Acknowledgements. This research was conducted as part of the Sea Around Us Project, initiated and funded by the Pew Charitable Trusts of Philadelphia, USA. We are grateful to A. Kitchingman and F. Valdez, both members of the Sea Around Us Project, for their help in our modelling efforts.

\section{LITERATURE CITED}

Adams NJ, Moloney C, Navarro R (1993) Estimated food consumption by penguins at the Prince Edward Islands. Antarct Sci 5:245-252

Ainley DG, Sydeman WJ, Norton J (1995) Upper trophic level predators indicate interannual negative and positive anomalies in the California Current food web. Mar Ecol Prog Ser 118:69-79

Ainley DG, Spear LB, Tynan CT, Barth JA, Pierce SD, Ford RG, Cowles TJ (2005) Physical and biological variables affecting seabird distributions during the upwelling season of the Northern California Current. Deep-Sea Res II 52:123-143

Au DW (1991) Polyspecific nature of tuna schools: shark, dolphin, and seabird associations. Fish Bull (Seattle) 89: 343-354

Au DW, Pitman RL (1988) Seabird relationships with tropical tunas and dolphins. In: Burger J (ed) Seabirds and other marine vertebrates. Competition, predation, and other interactions. Columbia University Press, New York, p $174-212$

Barrett RT, Krasnov YV (1996) Recent responses to changes in stocks of prey species by seabirds in the southern Barents Sea. ICES J Mar Sci 53:713-722

Barrett RT, Anker-Nilssen T, Gabrielsen GW, Chapdelaine G (2002) Food consumption by seabirds in Norwegian waters. ICES J Mar Sci 59:43-47

Barrett RT, Chapdelaine G, Anker-Nilssen T, Mosbech A, Montevecchi WA, Reid JB, Veit RR (2006) Seabird numbers and prey consumption in the North Atlantic. ICES J Mar Sci 63:1145-1158

Belda EJ, Sanchez A (2001) Seabird mortality on longline fisheries in the western Mediterranean: factors affecting bycatch and proposed mitigating measures. Biol Conserv 98:357-363

BirdLife International (2004) Tracking ocean wanderers: the global distribution of albatrosses and petrels. Results from the global Procellariiform tracking workshop, 1-5 September 2003, Gordon's Bay, South Africa. BirdLife International, Cambridge

Bisby FA (2000) The quiet revolution: biodiversity informatics and the internet. Science 289:2309-2312

Boyle P, Rodhouse P (2005) Cephalopods: ecology and fisheries. Blackwell Science, Oxford

Brooke MdeL (2004) The food consumption of the world's seabirds. Biol Lett 271 (Suppl 4):S246-S248

Bunce A (2001) Prey consumption of Australasian gannets (Morus serrator) breeding in Port Phillip Bay, southeast Australia, and potential overlap with commercial fisheries. ICES J Mar Sci 58:904-915

Cairns DK (1992) Bridging the gap between ornithology and fisheries science: use of seabird data in stock assessment models. Condor 94:811-824

Cairns DK, Chapdelaine G, Montevecchi WA (1991) Prey exploitation by seabirds in the Gulf of St. Lawrence. Can Spec Publ Fish Aquat Sci 113:277-291

Camphuysen K(CJ) (1995) Sooty and Manx shearwaters in the southern North Sea: an offshore perspective. Limosa $68: 1-9$

Carscadden JE, Montevecchi WA, Davoren GK, Nakashima BS (2002) Trophic relationships among capelin (Mallotus villosus) and seabirds in a changing ecosystem. ICES J Mar Sci 59:1027-1033

Cherel Y, Weimerskirch H (1996) Interactions between longline vessels and seabirds in Kerguelen waters and a method to reduce seabird mortality. Biol Conserv 75: 63-70

Cheung W, Alder J, Karpouzi V, Watson R, Lam V, Day C, Kaschner K, Pauly D (2005) Patterns of species richness in the high seas. Secretariat of the Convention on Biological Diversity, Montreal. Conv Biol Divers Tech Ser 20

Chown SL, Gaston KJ, Williams PH (1998) Global patterns in species richness of pelagic seabirds: the Procellariiformes. Ecography 21:342-350

Clua É, Grosvalet F (2001) Mixed-species feeding aggregation of dolphins, large tunas and seabirds in the Azores. Aquat Living Resour 14:11-18

Cooper J, Woehler EJ (1994) Consumption of Antarctic krill (Euphausia superba) by seabirds during summer in the Prydz Bay region, Antarctica. In: El-Sayed SZ (ed) Southern Ocean ecology: the BIOMASS perspective. Cambridge University Press, Cambridge, p 247-260

Costello MJ, Vanden Berghe E, Browman HI (eds) (2006) Theme section: ocean biodiversity informatics (OBI). Mar Ecol Prog Ser 316:201-310

Cowx IG (ed) (2003) Interactions between fish and birds: implications for management. Blackwell Science, Oxford

Cramp S (ed) (1985) Birds of the Western Palearctic, Vol 1. Oxford University Press, Oxford

Crawford RJM, Jahncke J (1999) Comparison of trends in abundance of guano-producing seabirds in Peru and southern Africa. S Afr J Mar Sci 21:145-156

Croll DA, Tershy BR (1998) Penguins, fur seals, and fishing: prey requirements and potential competition in the South Shetland Islands, Antarctica. Polar Biol 19:365-374

Croxall JP, Wood AG (2002) The importance of the Patagonian Shelf for top predator species breeding at South Georgia. Aquat Conserv Mar Freshw Ecosyst 12:101-118

Cuthbert R, Hilton G, Ryan P, Tuck GN (2005) At-sea distribution of breeding Tristan albatross Diomedea dabbenena and potential interactions with pelagic longline fishing in the South Atlantic Ocean. Biol Conserv 121:345-355

Davoren GK, Montevecchi WA (2003) Signals from seabirds 
indicate changing biology of capelin stocks. Mar Ecol Prog Ser 258:253-261

Duffy DC, Schneider DC (1994) Seabird-fishery interactions: a manager's guide. In: Nettleship DN, Burger J, Gochfeld $M$ (eds) Seabirds on islands. Birdlife Conserv Ser 1, Birdlife International, Cambridge, p 26-38

Duhamel G, Koubbi P, Ravier C (2000) Day and night mesopelagic fish assemblages off the Kerguelen Islands (Southern Ocean). Polar Biol 23:106-112

Dunning JB (ed) (1993) CRC handbook of avian body masses. CRC Press, Boca Raton, FL

Ellis HI, Gabrielsen GW (2002) Energetics of free-ranging seabirds. In: Schreiber EA, Burger J (eds) Biology of marine birds. CRC Mar Biol Ser, CRC Press, Boca Raton, FL, p 359-407

Fowler CW (1999) Management of multi-species fisheries: from overfishing to sustainability. ICES J Mar Sci 56: 927-932

Furness RW (1978) Energy requirements of seabird communities: a bioenergetics model. J Anim Ecol 47:39-53

Furness RW (1982) Competition between fisheries and seabird communities. Adv Mar Biol 20:225-307

Furness RW (2002) Management implications of interactions between fisheries and sandeel-dependent seabirds in the North Sea. ICES J Mar Sci 59:261-269

Furness RW, Birkhead TR (1984) Seabird colony distributions suggest competition for food supply during the breeding season. Nature 311:655-656

Furness RW, Hudson AV, Ensor K (1988) Interactions between scavenging seabirds and commercial fisheries around the British Isles. In: Burger J (ed) Seabirds and other marine vertebrates: competition, predation and other interactions. Columbia University Press, Cambridge, p 240-268

Gabrielsen GW (1994) Energy expenditure in arctic seabirds. $\mathrm{PhD}$ dissertation, University of Tromsø

Garthe S, Camphuysen K(CJ), Furness RW (1996) Amounts of discards by commercial fisheries and their significance as food for seabirds in the North Sea. Mar Ecol Prog Ser 136: $1-11$

Gjerke KM, Breide C (2003) Towards a strategy for High Seas Marine Protected Areas. Proc IUCN, WCPA, WWF Experts Workshop on High Seas Marine Protected Areas, 15-17 January 2003, Malaga, Spain. IUCN, Gland

Goldsworthy SD, He X, Tuck GN, Lewis M, Williams R (2001) Trophic interactions between the Patagonian toothfish, its fishery, and seals and seabirds around Macquarie Island. Mar Ecol Prog Ser 218:283-302

Golet GH, Irons DB, Costa DP (2000) Energy costs of chick rearing in black-legged kittiwakes (Rissa tridactyla). Can J Zool 78:982-991

Gould P, Ostrom P, Walker W (1997) Food of flesh-footed shearwaters Puffinus carneipes associated with high-seas driftnets in the Central North Pacific Ocean. Emu 97: 168-173

Gould P, Ostrom P, Walker W (1998) Foods of Buller's shearwaters (Puffinus bulleri) associated with driftnet fisheries in the central North Pacific Ocean. Notornis 45:81-93

Green K, Slip DJ, Moore GJ (1998) The take of fish species by seabirds and marine mammals in the Australian Fisheries Zone around Heard Island: the potential for competition with a commercial fishery. Polar Biol 20:273-280

Grémillet D, Wilson RP, Wanless S, Chater T (2000) Blackbrowed albatrosses, international fisheries and the Patagonian Shelf. Mar Ecol Prog Ser 195:269-280

Guzman JR, Myres MT (1983) The occurrence of shearwaters (Puffinus spp.) off the west coast of Canada. Can J Zool 61: 2064-2077
Harrison P (2004) Seabirds: an identification guide. Houghton Mifflin, New York

Horn HS (1966) Measurement of 'overlap' in comparative ecological studies. Am Nat 100:419-424

Huntington T, Frid C, Banks R, Scott C, Paramor O (2004) Assessment of the sustainability of industrial fisheries producing fish meal and fish oil. Report to the Royal Society for the Protection of Birds. Poseidon Aquatic Resource Management, Lymington

Hurlbert SH (1978) The measurement of niche overlap and some relatives. Ecology 59:67-77

Hyrenbach KD, Fernández P, Anderson DJ (2002) Oceanographic habitats of two sympatric North Pacific albatrosses during the breeding season. Mar Ecol Prog Ser 233: 283-301

Hyrenbach KD, Keiper C, Allen SG, Ainley DG, Anderson DJ (2006) Use of marine sanctuaries by far-ranging predators: commuting flights to the California Current System by breeding Hawaiian albatrosses. Fish Oceanogr 15:95-103

Ichii T, Naganobou M, Ogishima T (1996) Competition between the krill fishery and penguins in the South Shetland Islands. Polar Biol 16:63-70

ICES (2000) Report of the working group on seabird ecology. ICES CM 2000/C:04, available online at www.ices.dk/ reports/occ/2000/

Ito $\mathrm{S}$ (2002) Foraging areas of Short-tailed shearwaters during their northward migration along the Pacific coast of northern Japan. Ornithol Sci 1:159-162

Jahncke J (1998) Las poblaciones de aves guaneras y sus relaciones con la abundancia de anchoveta y la ocurrencia de eventos El Niño en el Mar Peruano. Bol Inst Mar Perú 17: $1-13$

Jennings S, Kaiser MJ, Reynolds JD (2001) Marine fisheries ecology. Blackwell Science, Oxford

Karpouzi VS (2005) Modelling and mapping trophic overlap between fisheries and the world's seabirds. MSc thesis, University of British Columbia, Vancouver

Kaschner K (2004) Modelling and mapping resource overlap between marine mammals and fisheries on a global scale. PhD thesis, University of British Columbia, Vancouver

Kaschner K, Pauly D (2004) Competition between marine mammals and fisheries: food for thought. Report for the Humane Society, Washington, DC

Kaschner K, Watson R, Trites AW, Pauly D (2006) Mapping world-wide distributions of marine mammal species using a relative environmental suitability (RES) model. Mar Ecol Prog Ser 316:285-310

Kitaysky AS, Hunt GL Jr, Flint EN, Rubega MA, Decker MB (2000) Resource allocation in breeding seabirds: responses to fluctuations in their food supply. Mar Ecol Prog Ser 206: 283-296

Koteja P (1991) On the relation between basal and field metabolic rates in birds and mammals. Funct Ecol 5:56-64

Lascara CM, Hofmann EE, Ross RM, Quentin LB (1999) Seasonal variability in the distribution of Antarctic krill, Euphausia superba, west of the Antarctic Peninsula. Deep-Sea Res I 46:951-984

Lilliendahl K, Solmundsson J (1997) An estimate of summer food consumption of six seabird species in Iceland. ICES J Mar Sci 54:624-630

Lorentsen SH, Klages N, Røv N (1998) Diet and prey consumption of Antarctic petrels Thalassoica antarctica at Svarthamaren, Dronning Maud Land, and at sea outside the colony. Polar Biol 19:414-420

Mårtensson PE, Gotaas ARL, Nordoy ES, Blix AS (1996) Seasonal changes in energy density of prey of northeast Atlantic seals and whales. Mar Mamm Sci 12:635-640 
Melvin EF, Parrish JK (eds) (2001) Seabird bycatch: trends, roadblocks, and solutions. University of Alaska Sea Grant AK-SG-01-01, Fairbanks, AK

Montevecchi WA (2002) Interactions between fisheries and seabirds. In: Schreiber EA, Burger J (eds) Biology of marine birds. CRC Mar Biol Ser, CRC Press, FL, p 527-556

Moore G, Jennings S (eds) (2000) Commercial fishing: the wider ecological impacts. The British Ecological Society, Ecol Iss Ser, Blackwell Science, Oxford

Morisita M (1959) Measuring of interspecific association and similarity between communities. Mem Fac Sci Kyushu Univ Ser E Biol 3:65-80

Muck P, Pauly D (1987) Monthly anchoveta consumption of guano birds, 1953 to 1982. In: Pauly D, Tsukayama I (eds) The Peruvian anchoveta and its upwelling ecosystem: three decades of change. ICLARM Stud Rev 15. IMARPE and ICLARM, Manila, p 219-233

Myers RA, Worm B (2003) Rapid worldwide depletion of predatory fish communities. Nature 423:280-283

Nagy KA (1989) Doubly-labelled water studies of vertebrate physiological ecology. In: Rundell PW, Ehleringer JR, Nagy KA (eds) Stable isotopes in ecological research. Springer Verlag, Berlin, p 270-287

Nagy KA, Girard IA, Brown TK (1999) Energetics of freeranging mammals, reptiles, and birds. Annu Rev Nutr 19: $247-277$

Nel DC, Nel JL, Ryan PG, Klages NTW, Wilson RP, Robertson G (2000) Foraging ecology of grey-headed mollymawks at Marion Island, southern Indian Ocean, in relation to longline fishing activity. Biol Conserv 96:219-231

Nel DC, Lutjeharms JRE, Pakhomov EA, Ansorge IJ, Ryan PG, Klages NTW (2001) Exploitation of mesoscale oceanographic features by grey-headed albatross Thalassarche chrysostoma in the southern Indian Ocean. Mar Ecol Prog Ser 217:15-26

Oro D, Ruiz X (1997) Exploitation of trawler discards by breeding seabirds in the north-western Mediterranean: differences between the Ebro Delta and the Balearic Islands areas. ICES J Mar Sci 54:695-707

Pauly D, Christensen V (1995) Primary production required to sustain global fisheries. Nature 374:255-257

Pauly D, Christensen V, Dalsgaard J, Froese R, Torres F Jr (1998) Fishing down marine food webs. Science 279: 860-863

Pauly D, Christensen V, Guénette S, Pitcher TJ, Sumaila UR, Walters CJ, Watson R, Zeller D (2002) Towards sustainability in world fisheries. Nature 418:689-695

Pauly D, Alder J, Bennett E, Christensen V, Tyedmers P, Watson R (2003) The future of fisheries. Science 302: 1359-1361

Pauly D, Watson R, Alder J (2005) Global trends in world fisheries: impacts on marine ecosystems and food security. Philos Trans R Soc Lond B Biol Sci 360:5-12

Reeves SA, Furness RW (2002) Net loss — seabird gain? Implications of fisheries management for seabirds scavenging discards in the northern North Sea. The Royal Society for the Protection of Birds, Sandy

Rodhouse PG, Prince PA, Trathan PN, Hatfield EMC, Watkins JL, Bone DG, Murphy EJ, White MG (1996) Cephalopods

Editorial responsibility: Howard Browman (Associate Editorin-Chief), Storebø, Norway and mesoscale oceanography at the Antarctic Polar Front: satellite tracked predators locate pelagic trophic interactions. Mar Ecol Prog Ser 136:37-50

Rodhouse PG, Olsson O, Anker-Nilssen P, Murray AWA (1998) Cephalopod predation by the king penguin Aptenodytes patagonicus from South Georgia. Mar Ecol Prog Ser 168:13-19

Rodhouse PG, Elvidge CD, Trathan PN (2000) Remote sensing of the global light fishing fleet: an analysis of interactions with oceanography, other fisheries and predators. Adv Mar Biol 39:261-303

Schoener TW (1970) Non-synchronous spatial overlap of lizards in patchy habitats. Ecology 51:408-418

Schreiber EA, Burger J (eds) (2002) Biology of marine birds. CRC Mar Biol Ser, CRC Press, Boca Raton, FL

Spear LB, Ainley DG (1999) Migration routes of sooty shearwaters in the Pacific Ocean. Condor 101:205-218

Sueyoshi EG (2000) Abundance of guano birds and its relation with fishery of Peruvian anchoveta from 1953 to 1999. Bol Inst Mar Perú 19:125-131

Tierney M, Hindell MA, Goldsworthy S (2002) Energy content of mesopelagic fish from Macquarie Island. Antarct Sci 14: 225-230

Tuck GN, Polacheck T, Bulman CM (2003) Spatio-temporal trends of longline fishing effort in the Southern Ocean and implications for seabird bycatch. Biol Conserv 114:1-27

Uttley J, Tatner P, Monaghan PT (1994) Measuring the daily energy expenditure of free-living Arctic terns (Sterna paradisaea). Auk 111:453-459

Verity PG, Smetacek V, Smayda TJ (2002) Status, trends and the future of the marine pelagic ecosystem. Environ Conserv 29:207-237

Votier SC, Furness RW, Bearhop S, Crane JE and 11 others (2004) Changes in fisheries discard rates and seabird communities. Nature 427:727-730

Wanless S, Harris MP, Redman P, Speakman JR (2005) Low energy values of fish as a probable cause of a major seabird breeding failure in the North Sea. Mar Ecol Prog Ser 294:1-8

Watson R, Kitchingman A, Gelchu A, Pauly D (2004) Mapping global fisheries: sharpening our focus. Fish Fish 5: 168-177

Watson R, Revenga C, Kura Y (2006) Fishing gear associated with global marine catches. I. Database development. Fish Res (Amst) 79:97-102

Weimerskirch H, Catard A, Prince PA, Cherel Y, Croxall JP (1999) Foraging white-chinned petrels Procellaria aequinoctialis at risk: from the tropics to Antarctica. Biol Conserv 87:273-275

Weimerskirch H, Inchausti P, Guinet C, Barbraud C (2003) Trends in bird and seal populations as indicators of a system shift in the Southern Ocean. Antarct Sci 15:249-256

Woehler EJ (1995) Consumption of Southern Ocean marine resources by penguins. In: Dann P, Norman I, Reilly P (eds) The penguins: ecology and management. Surrey Beatty \& Sons, Chipping Norton, p 266-294

Worm B, Lotze HK, Myers RA (2003) Predator diversity hotspots in the blue ocean. Proc Natl Acad Sci USA 100: 9884-9888

Submitted: August 31, 2006; Accepted: December 21, 2006 Proofs received from author(s): July 24, 2007 